Asian Economic and Financial Review

$\operatorname{ISSN}(e): \quad 2222-6737$

$\operatorname{ISSN}(p): \quad 2305-2147$

DOI: 10.18488/journal.aefr.2021.112.160.172

Vol. 11, No. 2, 160-172.

(C) 2021 AESS Publications. All Rights Reserved.

URL: www.aessweb.com

check for

\title{
FINANCIAL SECTOR REFORM AND ECONOMIC DEVELOPMENT IN NIGERIA
}

\author{
Abiola Ayopo \\ Babajide $^{1+}$ \\ iD Lawal Adedoyin \\ Ishola $^{2}$ \\ Adetiloye Kehinde \\ Adekunle $^{3}$ \\ Bede Uzoma \\ Achugamonu $^{4}$ \\ Akinjare Victoria \\ Bosede $^{5}$
}

\author{
${ }^{1,3, t, 5}$ Department of Banking and Finance, Covenant University, Ota, Nigeria. \\ ${ }^{2}$ Email:abiolababajide@covenantuniversity.edu.ng Tel:234803924953s \\ 'Email:Adetiloye.kehinde@covenantuniversity.edu.ng Tel:2347031000124 \\ 'Email:uzoma.achugamonu@covenantuniversity.edu.ng Tel:23490611s8201 \\ 'Email:victoria.akinjare@covenantuniversity.edu.ng Tel:2348025891218 \\ ${ }^{2}$ Department of Accounting and Finance, Landmark University, Omu Aran, \\ Kwara State, Nigeria. \\ 'Email:Lawal.adedoyin@lmu.edu.ng.Tel:2348035233567
}

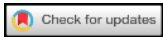

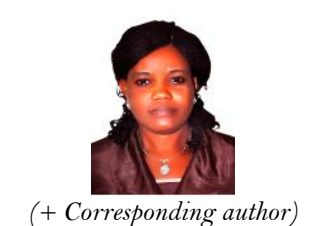

(+ Corresponding author)

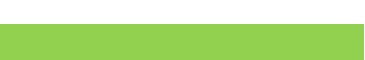

\begin{abstract}
Various reforms have been brought to bear on the financial system ostensibly to improve the country's macroeconomic variables and the standard of living of the people, among which are the financial reforms that were implemented in recent times. This study examines the impact of financial sector reform on the Human Development Index (HDI) following the recent statistics that show improvement in the HDI of Nigeria since 2005. The study employed several variables as a proxy for financial reforms and adopted the Granger causality test and vector error correction model to analyse the impact of the relationship for the period between 1980 and 2017. The findings revealed a negative long-run relationship between financial sector reform variables and HDI, except for owners' equity. The study also showed positive short-run dynamics between total savings to GDP and HDI. The study concluded that the recent improvements in HDI, which is the proxy for economic development, are not due to the financial sector's reforms; rather, some other influences in the economy could be responsible. The study, therefore, recommends a more inclusive reform agenda that will focus on economic development rather than economic growth.
\end{abstract}

Article History

Received: 14 December 2020 Revised: 27 January 2021 Accepted: 10 February 2021 Published: 24 February 2021

\section{Keywords \\ Human development index \\ Financial sector reform \\ Vector error correction \\ Inclusive growth \\ Financial liberalisation \\ Financial deepening \\ Economic development.}

\section{JEL Classification:}

Contribution/Originality: This paper contributes to the existing literature by exploring the effect of financial sector reform on citizenry's well-being. The study posits that the ultimate objective of financial sector reform is citizens' well-being through enhanced access to finance. Citizens well being is proxy by Human Development Index.

\section{INTRODUCTION}

The quest for economic development has been the main task of most governments across the globe. Governments' performance and success are often assessed based on the nation's economic development, which are direct reflections of government policies and reform agendas. At different times, the Nigerian government has evolved several policies and reforms in the quest for economic development. Economic development, in a practical sense implies the reduction or elimination of poverty, inequality and unemployment within the context of a growing 
economy (Todaro, 1977). Economic growth is described as the increase in the number of goods produced per head of the population over a period. There may be economic growth without development where the majority of the population still lives in poverty, the unemployment rate is high, the infant mortality rate is high and human development indices are low beyond an acceptable threshold. For some time, the Nigerian economy has been experiencing a persistent increase in the real economic growth rate of about $6-7 \%$ up until 2014, but this has been described as 'non-inclusive' growth because of the prevailing poverty rate and increasing low human development indices (Edet, 2015).

In a view to improving its economic development indices, the Nigerian government embarked on aggressive financial sector reforms for several reasons (Odeniran \& Udeaja, 2010). One of the major reforms in 2005 resulted in the reduction of 89 commercial banks to 25 through recapitalisation, mergers and acquisitions. These reforms have resulted in the emergence of stronger banks with a more efficient payment system and improved financial infrastructure (Iganiga, 2010). After the reform, bank credit to the economy increased by 10\% between 2010 and 2014, although the majority of the bank credit still skewed toward short-term maturities. Non-performing loans of the banks decreased substantially within the same period due to the decision of asset management company AMCON to buy up the non-performing loans (NPLs) of the energy sector, resulting in relative stability in the banking sector (Barungi, Ogunleye, \& Zamba, 2015). The adoption of a market-determined cash reserve requirement caused cash intensity and domestic savings to increase by $5.54 \%$ and $5.0 \%$, respectively. The continuous bank recapitalisation and the intervention of the regulatory authority bail-out policy for distressed banks invigorated public confidence in the country's financial institutions, thereby increasing savings further by $3.6 \%$ (Iganiga, 2010).

The 2013 statistics released by the World Bank and IMF showed improvement in Nigeria's HDI index, at 0.504 from 0.486 on the previous year, although still in the low human development category is an improvement from 2005. The Nigeria Human Development Index increased in value from 0.466 to 0.514 from 2005 to 2014 , representing an increase of $10.1 \%$ over the period or an average increase of $1.07 \%$ annually. Nigeria's 2014 Human Development Index of 0.524 is above the average of 0.493 for countries in the low human development region and above the average of 0.502 for countries in Sub-Saharan Africa. Nigeria's HDI was 0.530 in 2016 and stood at 0.532 in 2017. Life expectancy at birth also increased by 6.9 years, mean years of schooling improved by 0.2 years, and probable years of schooling improved by 2.3 years. The country's gross national income (GNI) per capita also increased by about 25.7\% between 1980 and 2013 (UNDP 2014 Report (Nigeria), 2014). The newly released data inspired the decision to investigate the role of financial sector reforms on Nigeria's economic development.

The Human Development Index (HDI) emphasises that people and their competences should be the ultimate criteria for measuring a country's development, not economic growth alone. The HDI summarises average attainment in crucial measurements of human development: a long and healthy life, quality education, and a decent standard of living. It is the geometric mean of normalised indices for each of the three dimensions that have been aggregated into the index. The health dimension is evaluated by life expectancy at birth; the education dimension is assessed by the mean of years of education for adults aged 25 years and above and expected years of schooling for children of school-entering age; the standard of living dimension is assessed by gross national income per capita; and the logarithm of income is used to reflect the weakening position of income with cumulative GNI. The composite index was obtained using geometric mean scores for the three dimensions of HDI indices. The HDI gives an overall index of economic development and is used to create an overall score between 0 and 1; countries closer to 1 are ranked higher and are perceived to be better than countries that are farther from 1 .

After 1986, the Nigerian government's primary reform agenda has been in the financial sector until recently. Emerging economies around the world, including Mexico, Columbia, South Korea, Argentina and South Africa, embarked on financial sector reforms at one time or another, mainly in the 1980s, when many nations suffered poor macroeconomic performance and had to turn to the IMF for assistance in order to enhance macroeconomic stability 
and sustainable economic growth. The IMF's prescription to the nations was the Structural Adjustment Programme (SAP). SAP advocated export-led growth, privatisation of institutions, deregulation, and liberalisation, emphasising the free market's efficiency. The nations were also required to devalue their currency against the dollar, relax import-export restrictions, cut down on government expenditure, increase taxes and remove price control and subsidies (Ogun \& Akinlo, 2011).

Financial sector reform was part of SAP's prescription for macroeconomic stability. The financial sector reform is required to improve the monetary policy's effectiveness, which emphasises indirect control of monetary instruments with greater reliance on the interplay of market forces. The main thrusts of the reform agenda are liberalisation of interest rate, removal of direct government intervention, strengthening the role of market forces in the allocation of resources, improving the capacity of the financial institution for domestic resource mobilisation efforts, enhancing the effectiveness of the monetary policy instrument, promoting competition and efficacy of the financial system by removing barriers to free entry and exit, and strengthening the supervisory roles of the regulators (Waheed, 2009). The financial system's need to act proactively to both strengthen the system and prevent systemic failure was a significant reason for the 2005 financial sector reforms in Nigeria (Imala, 2005). The ultimate aims of the reform agenda are to enhance the standard of living of the people through access to finance and promote economic growth and development within a stable financial system.

Previous studies explored the relationship between financial sector reform and economic growth, but none has explored the impact of these reforms on the well-being of the citizens of the country. Therefore, this study fills the gap in the literature by probing more critically if the reform agenda achieved its ultimate objective with a view to establishing a long-term relationship between financial sector reforms and economic development with regard to human development in Nigeria. The study is divided into five sections; after the background to the study, section two explains the theoretical framework and literature review, sector three describes the methodology employed in this study, section four presents the empirical results and discussion, and the last section focuses on the conclusion and policy implications of the study.

\section{THEORETICAL FRAMEWORK AND LITERATURE REVIEW}

\subsection{Theoretical Review}

The major breakthrough in the finance-growth nexus was in the pioneering work of McKinnon (1973) that described the financial sector as the primary driver of economic development and growth where the financial sector is completely liberalised. According to McKinnon, the financial sector responds passively to economic development if it is repressed, but it is the primary driver of the economic development process when it is liberalised. A repressed financial system is characterised by regulated interest rates on deposits and loans, direct control of credit allocation, credit expansion ceiling, and barriers to entry in the banking industry, which reduce competition. Williamson and Mahar (1998) agree that a liberalised financial sector would provide the necessary impetus for economic growth and development. In their view, there are six main reform areas that a nation must embark upon to liberalise the financial sector to provide the necessary support for the real sector. The reform areas are deregulation/liberalisation of interest rates, removal of credit controls, relaxation of entry-rules into the banking industry, bank autonomy, privatisation of state-owned banks and deregulating international capital flows. All of these reform areas had been embarked upon by the Nigerian government at one time or another. Financial sector reforms' primary focus is the liberalisation of the banking sector operations to ensure competition and safety of the system and reposition the sector to proactively perform its financial intermediation role in the economy efficiently, thereby enhancing economic development (Iganiga, 2010).

Reforms in the financial sector is the bedrock for building a formidable, transparent and efficient financial system that can support the mobilisation of domestic and foreign savings for investment, as well as deepen and broaden financial intermediation and enforce strict compliance with regulations and prudential guidelines for an 
increase in economic activities (Manasseh, Asogwa, Agu, \& Aneke, 2014). The need to attain an efficient and effective financial system by challenging the existing status quo drove the need for reforms (Ajayi, 2005). Reforms are deliberate actions by the government to jumpstart or fast track a process to achieve the desired objective and establish a movement towards a friendlier, market-oriented economy that will be all-inclusive (Okeke, 2007; Udah \& Obafemi, 2011). Lemo (2005) attested that the 2005 financial sector reforms agenda's primary objective was to achieve an efficient and sound financial sector. It was deliberately packaged to enhance the banking sector's capacity to provide the necessary support for the government's economic development agenda by performing its financial intermediation role efficiently. The safety of depositors' funds, repositioning of the banks to play active developmental roles in the Nigerian economy and the need for Nigerian banks to become major players in the subregion and global financial markets were fundamental reasons for the reform.

The debate on the impact of financial sector reform on economic growth has received much attention from researchers across the globe with mixed results and divergent views on variables employed and analysis methods. A standard view is that a well-supervised reform should result in financial sector development with the sector's depth to sustain economic development. Fry (1980) advocate for the unification of the fragmented financial market, which is the key to financial sector development. According to Fry, a well-supervised reform process will result in effective credit intermediation, liquidity, and risk-based management, which can sustain the financial system and enhance people's well-being.

The Nigerian financial sector has undergone significant changes in terms of the policy environment, several institutions, changes in the ownership structure of institutions, depth and breadth of markets, and substantial changes in the regulatory framework, which has resulted in a non-repressive financial system. With a wellfunctioning financial system, strong financial institutions and markets will emerge that will provide opportunities for all market participants to take advantage of by ensuring that funds are channelled to the most productive uses, which will, in turn, boost economic growth, improve income distribution and alleviate poverty. A well-functioning financial system also enhances broad access to finance, which is a critical factor in eliminating persistent income inequality and slow economic growth (Akinlo \& Owoyemi, 2012). Majeed (2016) identified inequalities as a significant reason for retarded economic growth in developing countries.

\subsection{Empirical Evidence}

Much empirical evidence exists in the literature on the relationship between financial sector reform and economic growth using different variables and analytical techniques. Akpansung and Gidigbi (2014) examined the implications of financial sector reforms on sectoral credit allocations and economic growth using the ordinary least squares estimation technique. The study found that despite the drastic reduction in the number of commercial banks during the reform period, credit allocated to the activity sectors (agriculture, mining and quarrying, manufacturing, communication, and oil and gas) improved significantly. The coefficients of mining and quarrying and oil and gas were statistically significant at the 0.05 level. Manasseh et al. (2014) also investigated the causal relationship between financial sector reforms and Nigeria's economic growth. To establish a connection, financial sector reforms were measured with the ratio of banking sector domestic credit to the private sector and capital flow for foreign direct investment, while economic growth was proxied with GDP per capita. Using a generalised linear regression method with quarterly time-series data, the result showed a bidirectional relationship between the banking sector domestic credit and per capita GDP; unidirectional causation was running from foreign direct investment to per capita GDP unidirectional causation was running from per capita GDP to private sector domestic credit. The study established that the banking sector's domestic credit and foreign direct investment were the significant policy variables that could be used to adjust economic growth.

In a study on financial sector reform and economic growth in Nigeria, Eta and Anaborie (2015), using panel data and a linear regression estimate, found a positive relationship between deposit money bank credit claims and 
economic growth and a negative relationship between them the lending rate and economic growth. They also found that an increase in bank loans and advances enhanced economic growth through income generated from such loans. Therefore, the study recommended the need for banks to enhance their credit appraisal and loan administration capacity to boost economic growth in Nigeria.

A review of existing literature showed that there is a gap in the literature, which this study is poised to fill by examining the relationship between financial sector reform and economic development. Economic development is defined here as the people's well-being in terms of health, education and income using the human development index as a proxy for economic development in Nigeria.

\section{RESEARCH METHODS}

\subsection{Theoretical Framework}

The hypotheses of neo-classical economists and McKinnon and Shaw posit that a non-repressive financial system is expected to lead to an increase in economic growth. Based on this assumption, this paper specifies a model designed to evaluate the impact of financial sector reform on economic development in Nigeria, covering the period between 1980 and 2017. A previous study model was used with a slight modification to capture the essence of the study. Iganiga (2010) identified indices of financial sector reforms: interest rate spread (IRS), the ownership structure of banks (OWR), capital base $(\mathrm{CAB})$, minimum rediscount rate (MRR) and cash reserve ratio (CRR). Owusu and Odhiambo (2014) used GDP per capita as a macroeconomic development indicator. Economic development goes beyond economic growth. It measures the essence of economic growth on people's living standards. The higher the HDI, the better its citizens' conditions to live and earn a living. The main idea behind the index is that people are the real value of any nation, and the richness of human lives should be the priority of any government.

The paper adopted the Granger causality approach to estimate possible causality between the variables used in this study. The test could show unidirectional, non-directional or bi-directional. The standard vector autoregressive (VAR) model for estimating the causal relationship between $Y_{t}$ and $X_{t}$ is stated as follows:

$$
\begin{aligned}
& Y_{t}=\alpha_{1}+\sum_{i=1}^{n} \beta_{i} X_{t-i}+\sum_{i=1}^{m} \gamma_{i} Y_{t-i}+e_{1 t} \\
& X_{t}=\alpha_{2}+\sum_{i=1}^{n} \theta_{i} X_{t-i}+\sum_{i=1}^{m} \delta_{i} Y_{t-i}+e_{.2 t}
\end{aligned}
$$

where: $e_{Y t} \sim \operatorname{IID}\left(0, \sigma_{Y}^{2}\right) ; e_{X t} \sim \operatorname{IID}\left(0, \sigma_{X}^{2}\right)$

Granger (1969) refers to variables' "prediction" rather than the general notion of "causality"and infers that in a VAR system, such as in Equations 1 and 2 , it is possible that (a) $Y_{t}$ 'causes' $X_{t}$; (b) $X_{t}$ 'causes' $Y_{t}$; (c) bi-directional feedback relations; and (d) $X_{t}$ and $Y_{t}$ are independent. This study tests the four possibilities since they force the study to conclude the direction of the causality of the six variables being tested.

To test the causal relationship hypotheses, the normal Wald $F$-statistics test or coefficient restriction was applied by Equation 3 below as follows:

$$
F=\frac{\left(R s s_{R}-R s s_{u} / M\right)}{R s s_{u} / n-k}
$$


This follows the $\mathrm{F}_{\mathrm{m}, \mathrm{n}-\mathrm{k}}$ distribution. Here, $\mathrm{k}=\mathrm{m}+\mathrm{n}+1$. We reject the null if the computed $\mathrm{F}$-value (statistics) exceeds the F-critical value and concludes that $X_{t}{ }^{\prime}$ causes' $Y_{t}$ and vice-versa. Rss ${ }_{\mathrm{u}}$ and Rss $\mathrm{R}_{\mathrm{R}}$ represent the sum of squared residual from unrestricted and restricted equations, respectively.

Hence, the model is specified in Equation 4 as follows:

$$
\mathrm{ECD}=\mathrm{F}(\mathrm{FSR})
$$

where ECD = Economic Development proxy by Human Development Index (HDI) and FSR = Financial Sector Reform proxy by IRS (interest rate spread), OWR (owners' equity), CRR (cash reserve ratio) and financial deepening indicators.

\subsection{Definition of Variables}

The study added financial deepening indicators because the expected result of financial reform is financial deepening and development. Hence, credit to the private sector as a percentage of GDP (CPS/GDP\%) was introduced. Total savings as a percentage of GDP(TS/GDP) were also added because effective financial reform should increase savings.

The interest rate spreads (IRS) measure the difference between deposit and lending rates; it shows a level of efficiency/inefficiency of the bank intermediation role and the level of development of the financial system. Bank interest rate spreads have several important implications for any economy's growth and development (Akinlo \& Owoyemi, 2012). Owners' equity $(O W R)$ is captured using banks' total assets less total liability, indicating owners' investment in businesses. Increasing owners' stakes in businesses is one of the financial sector reform targets. Cash reserve ratio $(C R R)$ is specified as a minimum fraction of bank customers' total deposits that the commercial banks have to hold as reserves either in cash or as deposits with the central bank. Our model is included because it is one of the variables often used by the regulatory authority to manage liquidity. Domestic credit to the private sector (\% of GDP) in Nigeria was measured at 12.59\% (World Bank Report, 2014). Domestic credit to the private sector denotes the private sector's financial resources, such as loans, trade credits, purchases of non-equity securities, and other accounts receivable that establish a claim for repayment. The ratio of total savings to \% of GDP shows the country's financial state and growth as household savings are the primary source of borrowing for banks and government. A well-implemented financial sector reform should enhance financial intermediations, which will, in turn, increase savings. A well-functioning financial system should show a progressive increase in the variables and is one of the targets of financial sector reform. Ultimately, a well-implemented financial sector reform should facilitate increased access to credit, which will result in inclusive growth and economic development.

Therefore, to capture the essence of this study, the model is modified and specified in Equation 5 below as follows:

$$
H D I=f(I R S, O W R, C R R, C P S / G D P, T S / G D P)
$$

The model was estimated and analysed using the vector error correction model. Using this method of analysis requires carrying out some pre-test analyses. To start, the variables were logged to eliminate any form of skew, which is common with finance and economic data. We then proceeded to carry out a unit root test using 'the Phillips-Perron (PP) unit root test analysis. These tests assessed the null hypothesis of a unit root in univariate time series $y$. All tests of the model are presented in Equation 6:

$$
y t=c+\delta t+a y t-1+e(t) .
$$

The null hypothesis restricts $a=1$. Variants of the test and appropriateness for the series with different growth characteristics restrict the drift and deterministic trend coefficients $c$ and $\delta$, respectively, to be $O$. The test accounts 
for serial correlations in the innovations process $e(t)$. The result was found to be more robust for stationarity testing. The next stage is to establish cointegration and the long-run relationship among the variables. Johansen cointegration techniques were found to be suitable for this purpose since the unit root result showed that all the variables were at the difference of the first order 1(1). The Johansen test is a superior technique that addresses the limitations of the Engle-Granger method. It provides comprehensive testing in the presence of multiple cointegrating relations and avoids a two-step estimation. Its maximum likelihood approach integrates the testing procedure into the procedure of model estimation, avoiding conditional assessments.

Moreover, the test provides a structure for testing restrictions on the cointegrating relations B and the adjustment speeds $\mathrm{A}$ in the vector error correction model. Two types of Johansen tests are reported-trace and eigenvaluewhich come with a few differences. The null hypothesis for the trace test is the number of cointegration vectors.

The subsequent analysis is error correction analysis. According to Arfanuzzaman (2014), a vector error correction (VEC) model is a controlled VAR with cointegration restrictions built into the specification. It is intended for use with non-stationary series that are known to be cointegrated. The cointegration term is known as the error correction term. The deviation from long-run equilibrium is corrected progressively through a series of partial short-run adjustments; this implies that a VEC is more subtle and flexible than merely using a VAR on firstdifferenced data. There are two primary specifications for error correction: the long run and the short run VECM. The vector error correction model (VECM) of Equation 1 is estimated in Equation 7 below as follows:

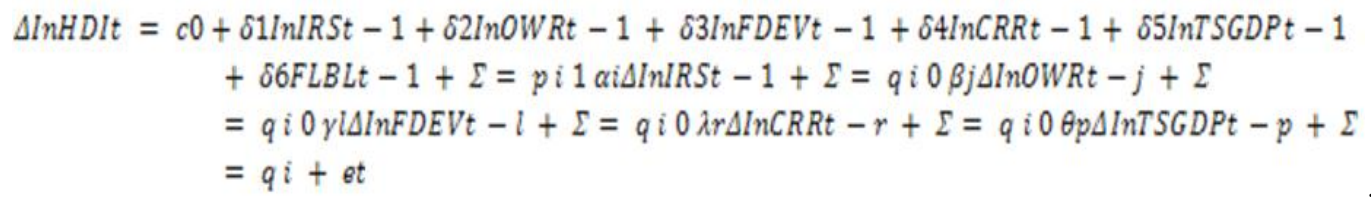

where: i) the coefficients $\alpha i, \beta j, \gamma l, \lambda r_{y}$ and $\theta p$ represent the short-run dynamics of the model; ii) the coefficients $\delta i$ represent the long-run multipliers corresponding to long-run relationships; iii) $c O$ is the drift, and iv) et is the white noise error term.

\section{EMPIRICAL RESULTS AND DISCUSSIONS}

\subsection{Unit Root Test Results}

The first stage involved in the empirical analysis is to ascertain the general characteristics of the model analysis variables, which encompassed the pre-test approach for all the observations captured within the study period. The pre-testing results and the regression analysis of the variables are presented below:

Table 1. Phillips-Perron (PP) Unit Root Test at Levels and First Difference.

\begin{tabular}{c|c|c|c|c|c}
\hline Variable & $\begin{array}{c}\text { PP Test @ } \\
\text { Levels }\end{array}$ & $\begin{array}{c}\text { PP Critical } \\
\text { Values }\end{array}$ & $\begin{array}{c}\text { Test @ First } \\
\text { Difference }\end{array}$ & $\begin{array}{c}\text { PP Critical } \\
\text { Values }\end{array}$ & Remark \\
\hline LHDI & 1.950475 & -2.954021 & -9.240380 & -2.957110 & $\mathrm{I}(1)$ \\
\hline LIRS & -2.355106 & -2.954021 & -10.30776 & -2.957110 & $\mathrm{I}(1)$ \\
\hline LOWR & -0.916037 & -2.954021 & -5.556988 & -2.957110 & $\mathrm{I}(1)$ \\
\hline LFDEV & -1.469490 & -2.954021 & -7.373385 & -2.957110 & $\mathrm{I}(1)$ \\
\hline LCRR & -0.132149 & -2.954021 & -3.370319 & -2.957110 & $\mathrm{I}(1)$ \\
\hline LTSGDP & -1.706477 & -2.954021 & -5.256928 & -2.957110 & $\mathrm{I}(1)$ \\
\hline
\end{tabular}

Table 1 above shows the unit root test results using the Phillips-Perron (PP) test. Evidence from the result shows that the unit root null hypothesis is accepted for the variables at the level. This implies the presence of a unit root in the data series. Analysis of time-series observations with unit root could lead to spurious results given these observations' stochastic trend. The study, therefore, proceeded to find the difference for all the variables at first 
difference. The PP test result at the first difference is presented in the second half of Table 1. The summary of the results indicates rejection of the unit root null hypothesis, which further implies the absence of a unit root for all the data series considered in the economic development model. It can be noted that all the observations achieved a stationary trend series after first differencing. This further shows that the variables are integrated to order 1 , as shown in Table 1 , and can be referred to as I(1).

Table 2. Cointegration Results.

\begin{tabular}{c|c|c|c|c|c|c|c}
\hline $\begin{array}{c}\text { Hypothesized } \\
\text { No. of CE(s) }\end{array}$ & Eigenvalue & $\begin{array}{c}\text { Trace } \\
\text { Statistics }\end{array}$ & $\begin{array}{c}\mathbf{0 . 0 5} \\
\text { Critical } \\
\text { Value }\end{array}$ & Prob.** & $\begin{array}{c}\text { Max- } \\
\text { Eigen } \\
\text { Statistic }\end{array}$ & $\begin{array}{c}\mathbf{0 . 0 5} \\
\text { Critical } \\
\text { Value }\end{array}$ & Prob.** \\
\hline None $*$ & 0.776378 & 119.8476 & 95.75366 & 0.0004 & $47.92959^{*}$ & 40.07757 & 0.0054 \\
\hline At most 1 * & 0.585975 & 71.91806 & 69.81889 & 0.0337 & 28.21853 & 33.87687 & 0.2036 \\
\hline At most 2 & 0.506105 & 43.69953 & 47.85613 & 0.1164 & 22.57386 & 27.58434 & 0.1924 \\
\hline At most 3 & 0.332618 & 21.12567 & 29.79707 & 0.3499 & 12.94059 & 21.13162 & 0.4577 \\
\hline At most 4 & 0.181538 & 8.185080 & 15.49471 & 0.4458 & 6.410497 & 14.26460 & 0.5611 \\
\hline At most 5 & 0.053946 & 1.774583 & 3.841466 & 0.1828 & 1.774583 & 3.841466 & 0.1828 \\
\hline
\end{tabular}

The results of the Johansen cointegration (see Table 2) revealed no cointegrated equation for the maximum eigen statistics and one cointegrated equation for the robust trace statistic. The presence of cointegration among the series trend implies the existence of a long-run relationship between the explained economic development proxy by HDI and the exogenous variables of interest rate spread, 'sowners' equity, financial development, cash reserve ratio and total savings' contribution to GDP.

\subsection{Estimated Long-Run Coefficients}

Table 3. Estimated Long-run Coefficients.

\begin{tabular}{c|c|c|c|c|c|c}
\hline CointEq: & C & LIRS(-1) & LOWR(-1) & LCRR(-1) & LFDEV2(-1) & LTSGDP \\
\hline Coefficients & 1.084549 & -0.014577 & 0.023234 & -0.017653 & -0.089189 & 0.011077 \\
\hline Std. Error & & $(0.00279)$ & $(0.00295)$ & $(0.00140)$ & $(0.01720)$ & $(0.01465)$ \\
\cline { 1 - 7 }$t$-statistic & {$[-5.23204]$} & {$[7.88116]$} & {$[-12.5846]$} & {$[-5.18408]$} & {$[0.75608]$} \\
\hline \multicolumn{2}{|l|}{ Note: Standard error and $t$-statistics in parenthesis as () and [], respectively. }
\end{tabular}

The analysis of the long-run coefficients, presented in Table 3 above, shows that all the variables of financial reforms except total savings to GDP have a significant effect on economic development proxy by HDI. The result shows that a long-run relationship exists between interest rate spread and economic development. A percentage change in interest rate spread leads to $0.015 \%$ changes in economic development proxy by HDI. The direction of impact shows a retarded effect on economic development in Nigeria; this implies that the financial sector reform has not really narrowed the spread between lending and deposit rates. Further analysis shows that the degree of the sensitivity of economic development to interest rate spread is inelastic but statistically significant. This result is similar to the findings of Obamuyi and Olorunfemi (2011); Essien (2012) and Eta and Anaborie (2015) whose studies revealed a significant negative effect of interest rate on economic growth. This implies that all the reforms on interest rates have not resulted in a significant positive effect on economic growth.

Evidence from the estimated long-run coefficient for 'sowners' equity revealed a significant direct relationship between 'sowners' equity and economic development, holding other factors constant. The analysis of the parameter estimate for 'sowners' equity indicates that a percentage change in 'sowners' equity results in a $0.023 \%$ change in economic development ceteris paribus. Detailed analysis of the results shows that the degree of the responsiveness of human development to the variations in 'sowners' equity is less than 1 . This implies that a proportionate change in 'sowners' equity brings about a less proportionate change in HDI. This is similar to findings by Iganiga (2010), who reported ownership structure to have a significant positive impact on cash intensity and domestic savings. This 
implies a significant boost in the efficiency of the banking sector as the private sector owns a more significant stake in the financial sector than the government, enabling efficient allocation of resources.

The cash reserve ratio indicates a significant inverse relationship with HDI. In specific terms, a percentage change in the cash reserve ratio consequently leads to a corresponding $0.018 \%$ change in human development indicator. The above evidence suggests that an increase in financial reforms through cash reserve ratio does not bring about a corresponding increase in human development indicators within the scope of the present study. Furthermore, a proportionate change in cash reserve ratio leads to a less proportionate change in HDI, assuming other determinant factors held constant. Thus, it could be observed from the results in Table 3 , that the degree of the responsiveness of economic development to the changes in commercial banks' cash reserve ratio is inelastic. Iganiga (2010) also found the cash reserve ratio to have a diminishing effect on cash intensity and financial width in Nigeria. This implies that the reform of CRR does not enhance economic development in the country.

Credit to the private sector, proxy for financial deepening and development as a financial reform measure plays a significant role in the determination of the economic development of any economy. Evidence from this study shows that financial development plays a dominant role in human development over the period considered within this study - a percentage change in credit to private sector results in a $0.089 \%$ change in human development. Hence, a complete $100 \%$ change in credit to private sector results in an $8.9 \%$ change in human development. This is similar to the findings of Adeleye, Osabuohien, Bowale, Matthew, and Oduntan (2018) and the conclusion of Babajide, Okunlola, Nwuba, and Lawal (2020a). However, the result of the estimated long-run coefficient of financial development shows a significant negative relationship between financial development and economic development in Nigeria. This is contrary to the findings of Ogun and Akinlo (2011), Akpansung and Gidigbi (2014), Manasseh et al. (2014), Eta and Anaborie (2015), and Akinjare, Babajide, Isibor, and Okafor (2016). This is where a proper definition of economic development becomes significant. While this study defines economic development as total well-being proxy by human development index, all the other studies defined economic development from a narrow income earned perspective (Al-Hilani, 2012; Babajide, Okunlola, Nwuba, \& Lawal, 2020b), which implies that a proportionate change in financial development leads to a less proportionate change in real economic development. Analysis of the estimated parameter for private sector credit shows a retarded effect on HDI by $0.09 \%$. Although total savings contribution to gross domestic product revealed direct relations with economic development in this study, it was not observed to be statistically significant. This further indicates that effective savings mobilization by the deposit money banks could be considered a vital financial reform channel that will significantly improve economic development in the future; this finding is similar to the conclusion of Babajide (2016).

Table 4. Error Correction Results.

\begin{tabular}{c|c|c|c|c|c|c}
\hline Error Correction & D(LHDI) & D(LIRS(-2)) & D(LOWR(-1) & D(LCRR(-1)) & D(LFDEV2(-1)) & D(LTSGDP) \\
\hline ECM $(-1)$ & -0.837443 & -0.010968 & 0.012028 & -0.012822 & -0.031025 & 0.048327 \\
\hline Standard Error & $(0.29241)$ & $(0.00582)$ & $(0.00922)$ & $(0.00885)$ & $(0.03457)$ & $(0.02192)$ \\
\hline$t$-statistic & {$[-2.86394]$} & {$[-1.88350]$} & {$[1.30431]$} & {$[-1.44951]$} & {$[-0.89742]$} & {$[2.20441]$} \\
\hline
\end{tabular}

The vector error correction model in Table 4 above shows the short-run dynamics of the system in analyzing the relationship between financial sector reforms and economic development in Nigeria. Evidence from this investigation shows that interest rate spread and total savings contribution to gross domestic product appears to have the most significant effect on economic development in the short run. A detailed analysis of the results indicates an inverse and significant relationship between interest rate spread and HDI in the short run. A percentage change in the interest rate spread results in a $0.011 \%$ change in HDI. This implies that in the short-run, the degree of the sensitivity of economic development to interest rate spread variations is inelastic. Thus, a 
percentage change in interest rate spread leads to a lower percentage change in economic development. Owners' equity appears to have a direct but elastic relationship with HDI, though not significant. Cash reserve ratio and financial development revealed an insignificant inverse but inelastic effect on economic development in the short run.

The contribution of total savings to gross domestic product appears to have the most significant effect on economic development in the short run. Specifically, a percentage change in the contribution of savings to the gross domestic product will result in a $0.048 \%$ change in economic development, holding other variables constant. A further observation of the result revealed a direct proportionality in the relationship between total savings to gross domestic product and economic development indicator. Hence, a proportion increase in total savings to gross domestic product brings about a corresponding increase in human development indicator. Total savings contribution to gross domestic product could be regarded as a significant determinant of economic development in the short run, which is similar to findings by Babajide, Okunlola, Adedoyin, Okafor, and Isibor (2020c); Adeleye et al. (2018); and Babajide (2012).

The error correction term $(-0.837)$ is correctly signed and statistically significant $(t$-stat -2.863$)$. This shows the short-run dynamics reflect the adjustment process from short-run disequilibrium to the long-run steady state in the system. The systemic speed of adjustment indicates that $83.7 \%$ of the short-run disequilibrium of the system could be corrected yearly. This shows a long adjustment process, which implies the system's ability to revert to its equilibrium state when induced by external shocks not determined within the system. It could, therefore, be observed that the system relatively exhibits a high rate of convergence to correct for short-run disturbances that could interfere with its equilibrium state.

\subsection{Granger Causality Test}

The short-run causality analysis, shown in Table 5, was conducted to determine the causal relationship among the variables in the economic development model. All through the output, the results indicated a unidirectional causality.

Table 5. Granger Causality Test (only significant pairs or results are shown in bold).

\begin{tabular}{l|l|c|c}
\hline \multicolumn{1}{l}{ Pairwise Granger Causality Tests } & Obs. & F-Statistic & Prob. \\
\hline Null Hypotheses: & 37 & 2.94574 & 0.0696 \\
\hline LIRS does not Granger-cause LHDI & 37 & 0.93583 & 0.4046 \\
\hline LHDI does not Granger-cause LIRS & & 0.13449 & 0.8747 \\
\hline LOWR does not Granger-cause LHDI & 37 & 3.10421 & 0.0612 \\
\hline LHDI does Granger-cause LOWR & & 1.66326 & 0.2084 \\
\hline LCRR does not Granger-cause LHDI & 37 & 2.53944 & 0.0976 \\
\hline LHDI does Granger-cause LCRR & & 0.82478 & 0.4491 \\
\hline LFDEV2 does not Granger-cause LHDI & 37 & 3.48574 & 0.0450 \\
\hline LHDI does Granger-cause LFDEV2 & & 2.89767 & 0.1694 \\
\hline LCRR does not Granger-cause LIRS & & & 0.0756 \\
\hline LIRS does Granger-cause LCRR
\end{tabular}

In Table 5 the results of the test show a unidirectional causality from interest rate spread to HDI, which implies that interest rate spread do Granger-cause HDI and HDI 'Granger-causes owners' equity. It was also observed that HDI does Granger-cause cash reserve ratio, while the cash reserve ratio does not Granger-cause HDI, and HDI does Granger-cause financial development, while financial development does not Granger-cause HDI. There is no significant causal relationship between total savings contribution to GDP and HDI. Neither 'sowners' equity nor interest rate spread Granger-cause each other. A unidirectional causality was observed from the interest rate spread to the cash reserve ratio, which suggests that interest rate spread can Granger-cause cash reserve ratio. Interest rate spread and private sector credit have no directional causality. Likewise, interest rate 
spread and total savings to GDP, cash reserve ratio and 'sowners' equity, private sector credit and 'sowners' equity, total savings to GDP and owners' equity, private sector credit to cash reserve ratio, total savings to GDP and cash reserve ratio and, finally, total savings to GDP and private sector credit all suggest no causal relationship among their respective Granger causality results.

\section{POLICY IMPLICATIONS, CONCLUSION AND RECOMMENDATIONS}

This study investigated the relationship between financial sector reform and human development in Nigeria using the Johansen cointegration test and vector error correction model. The Phillips-Perron unit root test result showed that the series is not stationary at level but stationary at the first order for all the variables, which makes the cointegration and vector error correction analysis possible. The cointegration result shows the existence of a long-run trend among the variables. The long-run estimates revealed a negative relationship between interest rate spread, cash reserve ratio and financial development variables and economic development, which is contrary to expectation. However, owners' equity is correctly signed and significant at $5 \%$, and the result of total savings as a percentage of GDP, although correctly signed, is not significant. The result of the vector error correction also follows the same trend except that 'sowners' equity is not significant in the short run, while total savings as a percentage of GDP is the most significant and correctly signed variable that explains economic development in the short run. The causality test showed that only interest rate spread Granger-causes economic development, while economic development does not Granger-cause owners' equity, cash reserve ratio, financial development or and total savings as a percentage of GDP.

As a result of the findings, it is concluded that financial sector reform has not positively enhanced economic development in Nigeria, rather the impact is generally negative both in the short run and in the long run, except for its impact on total savings as a percentage of GDP in the short run and owners' equity in the long run. There is a need to revisit the reform agenda and zero it down to focus on economic development rather than on economic growth. The interest rate differential is still very high, which implies that financial intermediation is not as effective as it should be to reduce the access to finance gap. This implies that the financial sector reform has not achieved its full objective in this regard.

Therefore, it can be concluded that recent improvements in HDI statistics is not as a result of the effectiveness of the financial sector reform but that other factors, such as rebasing of the GDP and redefining unemployment and underemployment, may be a critical factor for the improvement of HDI statistics. The policy implication is that the government should evolve a reform agenda that will target economic development rather than focus on economic growth. This can be achieved by driving inclusive growth, which will target human development in terms of education, health and general well-being of the people.

The financial sector reform agenda should focus on savings mobilization, and if savings increase, interest rate spread will be narrowed down, meaning the banks would have enough funds to extend to the private sector in the form of loans and advances, which will aid the development of the real sector.

Funding: This research is funded by Covenant University.

Competing Interests: The authors declare that they have no competing interests.

Acknowledgement: All authors contributed equally to the conception and design of the study.

\section{REFERENCES}

Adeleye, N., Osabuohien, E., Bowale, E., Matthew, O., \& Oduntan, E. (2018). Financial reforms and credit growth in Nigeria: empirical insights from ARDL and ECM techniques. International Review of Applied Economics, 32(6), 807-820.

Ajayi, M. (2005). Banking sector reforms and bank consolidation: Conceptual framework. CBN Bullion, 29(2), $2-10$.

Akinjare, V. A., Babajide, A., Isibor, A. A., \& Okafor, T. C. (2016). Monetary policy and its effectiveness on economic development in Nigeria. International Business Managemnet, 10(22), 5336-5340. 
Akinlo, A. E., \& Owoyemi, B. O. (2012). The determinants of interest rate spreads in Nigeria: An empirical investigation. Modern Economy, 3(07), 837-845.

Akpansung, A. O., \& Gidigbi, M. O. (2014). Recent banking reforms in Nigeria: Implications on sectoral credit allocation and economic growth. International Journal of Business and Social Science, 5(1), 91-104.

Al-Hilani, H. (2012). HDI as a measure of human development: A better index than the income approach. Journal of Business and Management, 2(5), 24-28.Available at: https://doi.org/10.9790/487x-0252428.

Arfanuzzaman, M. (2014). The long-run dynamic relationship between broad money supply and the GDP of Bangladesh: A VECM approach. Developing Country Studies, 4(14), 167-178.

Babajide, A. A. (2012). Effects of microfinance on micro and small enterprises (MSEs) growth in Nigeria. Asian Economic and Financial Review, 2(3), 463-477.

Babajide, A. A. (2016). Microsavings mobilisation innovations and poverty alleviation in Nigeria. Savings and Development, 40(1), 1-28.

Babajide, A. A., Okunlola, F. A., Nwuba, E., \& Lawal, A. I. (2020a). Wagner proposition in Nigeria: An econometric analysis. Heliyon, 6(8), e04680.Available at: https://doi.org/10.1016/j.heliyon.2020.e04680.

Babajide, A. A., Okunlola, F. A., Nwuba, E., \& Lawal, A. I. (2020b). Financial stability and entrepreneurship development in subSahara Africa: Implications for sustainable development goals. Cogent Social Sciences, 6(1), 1798330.

Babajide, A., Okunlola, F. A., Adedoyin, L., Okafor, T., \& Isibor, A. (2020c). Analysis of banks profitability: Domestic and foreign comparison. WSEAS Transactions on Business and Economics, 17, 946-955.Available at: https://doi.org/10.37394/23207.2020.17.93.

Barungi, B., Ogunleye, E., \& Zamba, C. (2015). Nigeria 2015, Africa economic outlook, Regional Development and Spatial Inclusion, African Development Bank, Organisation for Economic Co-operation and Development, United Nations Development Programme (2015). Avalable at: http://dx.doi.org/10.1787/aeo-2015-en. Retrieved from: https://www.afdb.org/fileadmin/uploads/afdb/Documents/Publications/AEO2015_EN.pdf.

Edet, L. I. (2015). The paradox of economic growth without development in Nigeria. Journal of Humanities and Social Science, $20(5), 64-77$.

Essien, A. V. (2012). An assessment of the impacts of banking sector reforms in Nigeria.

Eta, A. E., \& Anaborie, M. B. (2015). Financial sector reforms and economic growth in Nigeria. International Journal of Economics, Commerce, and Management, 3(9), 150 - 171.

Fry, M. J. (1980). Money and capital or financial deepening in economic development. Journal of Money, Credit, and Banking, $10(4), 464-475$.

Granger, C. W. (1969). Investigating causal relations by econometric models and cross-spectral methods. Econometrica: Journal of the Econometric Society, 37(3), 424-438.Available at: https://doi.org/10.2307/1912791.

Iganiga, B. (2010). Evaluation of the Nigerian financial sector reforms using behavioral models. Journal of Economics, 1(2), 65-75.

Imala, O. I. (2005). Challenges of banking sector reforms and bank consolidation in Nigeria. CBN Bullion, 29(2), 25-36.

Lemo, T. (2005). Regulatory oversight and stakeholder protection. Paper presented at the In A Paper Presented at the BGC Mergers and Acquisitions Interactive Seminar, held at Eko Hotels and Suite, 24th June.

Majeed, M. T. (2016). Economic growth, inequality and trade in developing countries. International Journal of Development Issues, 15(3), 240-253.Available at: https://doi.org/10.1108/IJDI-02-2016-0011.

Manasseh, C. O., Asogwa, F., Agu, D., \& Aneke, G. (2014). Economic growth in Nigeria: Evidence from the appraisal of financial sector reforms and its causal effects. IOSR Journal Of Humanities And Social Science (IOSR-JHSS), 19(5), o1-10.

McKinnon, R. I. (1973). Money and capital in economic development. Washington, D.C: The Brookings Institution.

Obamuyi, T. M., \& Olorunfemi, S. (2011). Financial reforms, interest rate behaviour and economic growth in Nigeria. Journal of Applied Finance and Banking, 1(4), 39-55.

Odeniran, S. O., \& Udeaja, E. A. (2010). Financial sector development and economic growth: Empirical evidence from Nigeria. Economic and Financial Review, 48(3), $91-124$. 
Ogun, T. P., \& Akinlo, A. E. (2011). Financial sector reforms and the performance of the Nigerian economy. The Review of Finance and Banking, 3(1), 47 -60.

Okeke, M. (2007). Economic reforms: A tool for sustainable service delivery. Zenith Economic Quarterly, 1(3), 6 - 11.

Owusu, E. L., \& Odhiambo, N. M. (2014). Financial liberalisation and economic growth in Nigeria: An ARDL-bounds testing approach. Journal of Economic Policy Reform, 17(2), 164-177.Available at: https://doi.org/10.1080/17487870.2013.787803.

Todaro, M. P. (1977). Economic for a developing world. London: Longman.

Udah, E. B., \& Obafemi, F. N. (2011). The impact of financial sector reforms on agricultural and manufacturing sectors in Nigeria. Journal of Sustainable Development in Africa, 13(8), $193-213$.

UNDP 2014 Report (Nigeria). (2014). Human development report 2014 makes a case for sustaining human progress by reducing vulnerabilities and building resilience. Retrieved from: http://hdr.undp.org/sites/default/files/hdr 14-report-en-1.pdf.

Waheed, A. (2009). Financial sector reforms and economic growth: A time-series data analysis for Pakistan. V. R. F. Series No. 452, Nov. 2009, Institute of Developing Economies, Japan External Trade Organization.

Williamson, J., \& Mahar, M. (1998). A survey of financial liberalisation. Princeton Essays in International Finance, No. 211.

World Bank Report. (2014). Nigeria economic report: Improved economic outlook in 2014, and prospects for continued growth look good. Retrieved from: https://www.worldbank.org/en/country/nigeria/publication/nigeria-economic-reportimproved-economic-outlook-in-2014-and-prospects-for-continued-growth-look-good. 